\title{
REGIONAL DISTRIBUTION OF STEROID SULFATASE IN THE RAT EPIDIDYMAL DUCT. ENZYME-HISTOCHEMICAL, IMMUNO-HISTOCHEMICAL AND BIOCHEMICAL STUDIES ${ }^{1}$.
}

\author{
Jun-Iahi KAWANO, Tsutomu OINUMA, Eizo AIKAWA* and Tatsuo SUGANUMA² \\ Department of Anatomy, Miyazaki Medical College, Miyazaki 889-16 and Department of Anatomy*, \\ Tokyo Women's Medical College, Shinjuku, Tokyo 162
}

Received for publication May 21, 1990 and in revised form August 31, 1990

\begin{abstract}
Regional distribution of steroid sulfatase was studied in the rat epididymal duct by enzymehistochemical, immuno-histochemical and biochemical methods. A large amount of the enzyme was localized in the proximal part of the caput. This specific localization resulted from regional differences in the amount of the enzyme in principal cells, major constituents of the epithelium. In principal cells the amount of the enzyme, largest in the proximal part of the caput, drastically decreased caudally. In the corpus and cauda, principal cells possessed trace amounts of the enzyme, while clear cells had a large amount. Distribution of the enzyme generally agreed with that of estradiol binding sites.
\end{abstract}

Mammalian steroid sulfatase (steryl-sulfate sulfohydrolase, EG 3.1.6.2) is a microsomal enzyme catalyzing hydrolysis of $3 \beta$-hydroxy steroid sulfates, including cholesteryl sulfate, dehydroepiandrosterone sulfate (DHEAS), and estrone sulfate. The enzyme is the same as arylsulfatase $\mathrm{C}$, one of the arylsulfate sulfohydrolases (EC 2.1.6.1) (6).

It has been thought that steroid sulfatase functions in the conversion of a relatively inert form of steroid, suitable for transport or storage, to hormonally active estrogens or to their precursors in target tissues (3). Therefore, analysis of the distribution of the enzyme is fundamental to understanding the mechanism of estrogen action.

We have developed a sensitive enzymehistochemical method for identifying steroid sulfatase (5) and produced a monoclonal antibody against the enzyme for application in immuno-histochemistry (7). In the present study, using enzyme-histochemical, immuno-histochemical and biochemical

\footnotetext{
1 This study was supported in part by Grant-in-Aids for Scientific Research (02770016, 02670014) from the Ministry of Education, Science and Culture.

2 All correspondence should be sent to Dr. Tatsuo Suganuma, Department of Anatomy, Miyazaki Medical College, Miyazaki 889-16.
}

methods, we examined the distribution of steroid sulfatase in the epididymis, which is known to be a target organ of estrogen as well as androgen (11).

\section{MATERIALS AND METHODS}

Chemicals: Phenylmethanesulfonyl fluoride (PMSF), 4-methylumbelliferyl sulfate (MUS), 6bromo-2-naphthyl sulfate (BNS), dehydroepiandrosterone sulfate (DHEAS), bovine serum albumin (BSA), and rat liver acetone powder were purchased from Sigma Chemical Co. (St. Louis, USA). Tritiated DHEAS $(603.1 \mathrm{GBq} / \mathrm{mmol})$ was purchased from New England Nuclear Corp. (Boston, USA). Leupeptin and pepstatin A were from Peptide Institute Inc. (Osaka, Japan).

Antibodies: P42C2, a monoclonal antibody specific to rat steroid sulfatase (7), was used. Antimouse IgG goat Fab' conjugated with horseradish peroxidase was purchased from MBL (Nagoya, Japan). Before use, the secondary antibody was incubated for $2 \mathrm{hr}$ at room temperature with about $1 \mathrm{mg} /$ $\mathrm{ml}$ rat liver acetone powder to reduce non-specific binding to tissue sections. Normal mouse IgG was obtained from Wako Pure Chemical Industries (Osaka, Japan).

Animals: Male Wistar rats (10-15 weeks old) 
were kept in a temperature and light controlled room $\left(22^{\circ} \mathrm{C}, \mathrm{LD} 12: 12\right.$ with light from 7:00 to 19:00). Food and water were available ad libitum. Epididymides were dissected out immediately after killing rats under deep diethyl ether anesthesia.

Immuno-affinity chromatography: Specificity of P42C2 to rat epididymal steroid sulfatase was confirmed by immuno-affinity chromatography. P42C2 $(10 \mathrm{mg})$ and normal mouse IgG $(10 \mathrm{mg})$ were respectively coupled to about $2 \mathrm{ml}$ of $\mathrm{CNBr}$-activated Sepharose 4B (Pharmacia Fine Chemicals, Uppsala, Sweden). As described in our previous report (6), microsomes were prepared from about $12 \mathrm{~g}$ of rat epididymides, solubilized in about $26 \mathrm{ml}$ of $20 \mathrm{mM}$ Tris-HCl buffer ( $\mathrm{pH} \mathrm{8.0)}$ ) containing 1\% Triton X$100,0.5 \mathrm{M} \mathrm{NaCl}$, and protein inhibitors $(250 \mu \mathrm{M}$ PMSF, $2.5 \mu \mathrm{M}$ leupeptin, and $2.5 \mu \mathrm{M}$ pepstatin A), and then applied to a column $(2 \mathrm{ml})$ of P42C2Sepharose equilibrated with the solubilizing buffer. After washing with the same buffer, the column was eluted with $10 \%$ dioxane containing $0.5 \mathrm{M} \mathrm{NaCl}$, $20 \mathrm{mM}$ Tris, and $0.3 \%$ Triton X-100 (adjusted to $\mathrm{pH} 11.0$ with ammonium hydroxide). As a control experiment, normal mouse IgG-Sepharose column $(2 \mathrm{ml})$ was used. Protein concentration was determined with bicinchoninic açid (13). In order to assay steroid sulfatase, aliquots $(10 \mu \mathrm{l})$ of samples were incubated with MUS solution (cited below).

\section{Histochemical studies}

Light microscopic enzyme-histochemistry: Epididymides were fixed with acetone for $4 \mathrm{hr}$ at $4^{\circ} \mathrm{C}$. Fixed tissues were carried through $10 \%, 15 \%$, and $20 \%$ sucrose in phosphate buffered saline (PBS) (4 hr to overnight), embedded in OCT compound (Miles Lab., Naperville, USA), frozen in liquid nitrogen, and sectioned at $10 \mu \mathrm{m}$ thickness with a Leitz 1720 cryostat. An azo coupling dye method (14) was used for the visualization of enzyme activity. Sections were incubated for $5 \mathrm{hr}$ at $37^{\circ} \mathrm{C}$ on a semipermeable membrane, which was interposed between tissue sections and agar gel medium (1.52\%) containing BNS (0.68 $\mathrm{mg} / \mathrm{ml})$, Fast Blue B $(0.36 \mathrm{mg} / \mathrm{ml})$, and $0.2 \mathrm{M}$ imidazole-acetate buffer ( $\mathrm{pH}$ 6.1). After removing the gel, the membrane with the sections was fixed in formaldehyde vapor and mounted with glycerolgelatine. As a control experiment, specimens were incubated with a substrate-free medium.

Electron microscopic enzyme-histochemistry: Epididymides were perfused via the ascending aorta with PBS and then with $1 \%$ glutaraldehyde in $0.1 \mathrm{M}$ cacodylate buffer $(\mathrm{pH} 7.2)$ containing $5 \%$ sucrose. The organs were removed and minced in the same fixative described above. After 30 min fixation, minc- ed tissue was rinsed with $0.1 \mathrm{M}$ imidazole- $\mathrm{HCl}$ buffer (pH 7.5) containing 5\% sucrose. Enzyme activity was electron microscopically visualized in the tissues by a metal precipitation method (5). Briefly, the specimens were incubated for $1-2 \mathrm{hr}$ at $37^{\circ} \mathrm{C}$ with a medium containing $1 \mathrm{mM}$ MUS, $1 \%$ barium chloride, $0.1 \mathrm{M}$ imidazole-HCl buffer ( $\mathrm{pH} 7.5$ ), and $5 \%$ sucrose. After washing with cacodylate buffer, specimens were postfixed with osmium tetroxide and further treated according to the usual procedure for electron microscopy. The specimens for a control were incubated with a substrate-free medium.

Light microscopic immuno-histochemistry: Tissues were fixed with acetone for $4 \mathrm{hr}$ at $4^{\circ} \mathrm{C}$. Aldehyde fixative reduced the immuno-histochemical staining to some extent at the light microscopic level. Frozen blocks, prepared as described above, were sectioned at 10-20 $\mu \mathrm{m}$ thickness with a cryostat, dried on glass slides, and rinsed with PBS. Sections were treated with $10 \%$ normal goat serum in PBS containing $1 \%$ BSA (BSA-PBS) for $1 \mathrm{hr}$ at room temperature and incubated for $12-24 \mathrm{hr}$ at $4^{\circ} \mathrm{C}$ with $40 \mu \mathrm{g} / \mathrm{ml} \mathrm{P} 42 \mathrm{C} 2$ in BSA-PBS, then rinsed with PBS and treated with antimouse IgG goat Fab' conjugated with horseradish peroxidase for $12-24 \mathrm{hr}$ at $4^{\circ} \mathrm{C}$. After rinsing with PBS, sections were incubated with $0.02 \%$ diaminobenzidine in $50 \mathrm{mM}$ Tris-HCl buffer ( $\mathrm{pH}$ 7.6) (DAB solution) containing $0.003 \% \mathrm{H}_{2} \mathrm{O}_{2}$ for $7 \mathrm{~min}$. As a control experiment, tissue sections were treated with BSAPBS or normal mouse IgG $(40 \mu \mathrm{g} / \mathrm{ml})$ instead of primary antibody.

Electron microscopic immuno-histochemistry: Epididymides were perfused with $4 \%$ paraformaldehyde in PBS containing $5 \%$ sucrose, and cut into small pieces in the same fixative. After $1 \mathrm{hr}$ fixation, frozen blocks were prepared and sectioned as described above. Cryostat sections were treated with monoclonal antibody and then with secondary antibodies in the same manner as for light microscopic immunohistochemistry. Treated sections were fixed with $1 \%$ glutaraldehyde in PBS for $5 \mathrm{~min}$, rinsed with PBS, preincubated in DAB solution containing $1 \%$ dimethyl sulfoxide to facilitate the penetration of $\mathrm{DAB}$ without $\mathrm{H}_{2} \mathrm{O}_{2}$ for $30 \mathrm{~min}$, and then incubated with the complete DAB solution containing $\mathrm{H}_{2} \mathrm{O}_{2}$ for 7 min. After washing with PBS, they were postfixed with 1\% osmium tetroxide in $0.1 \mathrm{M}$ phosphate buffer $(\mathrm{pH} 7.4)$ for $30 \mathrm{~min}$, dehydrated with a graded series of ethanol, and then embedded in Epon 812. Ultrathin sections cut with an LKB Ultrotome were observed with a JEM 1200EX electron microscope without counterstaining. Control experiments were performed as described above. 


\section{Biochemical analysis}

Epididymides perfused with $0.15 \mathrm{M} \mathrm{NaCl}$ were divided into six segments as shown Fig. 2, roughly corresponding to the segmentation of Reid and Cleland (9). Each of the segments was homogenized in about 100 volumes of $10 \mathrm{mM}$ Tris-HCl buffer $(\mathrm{pH}$ 7.6) with a Teflon-glass homogenizer after freezing and thawing. Slurries were centrifuged at $150 \times \mathrm{g}$ for $1 \mathrm{~min}$ to remove connective tissue and unbroken cells. Supernatants were frozen at $-85^{\circ} \mathrm{C}$ until use. Protein concentration was determined by the method of Bradford (2).

By a modification of the method of Meyer et al. (8), steroid sulfatase was assayed as arylsulfatase C. Samples $(10-40 \mu \mathrm{g}$ protein) were incubated in $0.5 \mathrm{ml}$ of $0.2 \mathrm{M}$ phosphate buffer ( $\mathrm{pH} 8.0$ ) containing $1 \mathrm{mM}$ MUS at $37^{\circ} \mathrm{C}$ for $30 \mathrm{~min}$. In the original method, incubation was performed for $5 \mathrm{hr}$ in order to detect a low activity of leukocytes. Sufficient activity was detected by $30 \mathrm{~min}$ incubation in the present study. After adding $3 \mathrm{ml}$ of $0.1 \mathrm{M}$ glycine buffer $(\mathrm{pH} 10.3)$, fluorescence was measured at $450 \mathrm{~nm}$ with an excitation wavelength of $360 \mathrm{~nm}$ using a Hitachi Type 650-
40 spectrophotofluorometer. Amount of the product was estimated from fluorescence values of 0 and $30 \mathrm{~min}$ incubations. Incubation without samples showed negligible fluorescence.

The enzyme was also assayed using a physiological substrate, DHEAS. Samples were incubated in $200 \mu \mathrm{l}$ of $0.1 \mathrm{M}$ imidazole- $\mathrm{HCl}$ buffer (pH 6.0) containing $8 \mu \mathrm{M}$ cold DHEAS, $0.305 \mu \mathrm{M}$ $\left[{ }^{3} \mathrm{H}\right]$-DHEAS, and $0.3 \%$ Triton $\mathrm{X}-100$ for $2 \mathrm{hr}$ at $37^{\circ} \mathrm{C}$. The amount of liberated steroid was measured as described previously (6). Control experiments were performed by not adding the samples to the reaction mixture.

Our preliminary experiments using purified rat liver steroid sulfatase showed that enzymatic activity was proportional to the amount of enzyme under conditions used.

\section{RESULTS}

Specificity of P42C2 to epididymal steroid sulfatase: Immuno-affinity chromatography of solubilized epididymal microsomes showed specific binding of

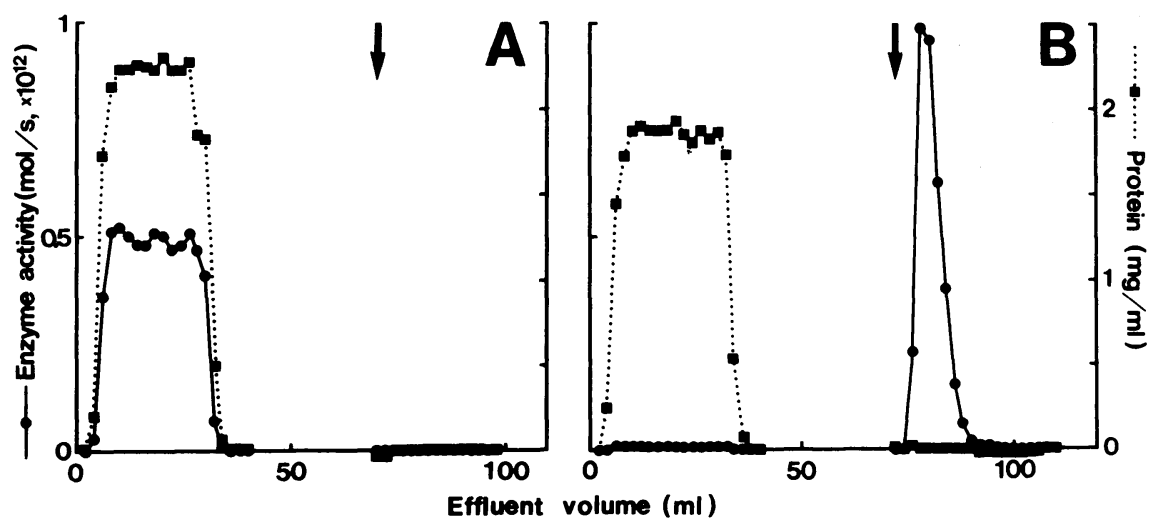

Fig. 1. Specific binding of epididymal steroid sulfatase to P42C2-Sepharose. A: Solubilized epididymal microsomes were applied to a column of normal mouse IgG-Sepharose. All of the enzyme and other proteins passed through the column. B: P42C2Sepharose affinity chromatography. Although almost all of proteins passed through the column, over $98 \%$ of the enzyme was bound to the column. About $60 \%$ of the bound enzyme was eluted with an alkaline solution containing $10 \%$ dioxane. In the eluate, protein could not be detected (less than $10 \mu \mathrm{g} / \mathrm{ml}$ ). Arrows indicate the start of elution.

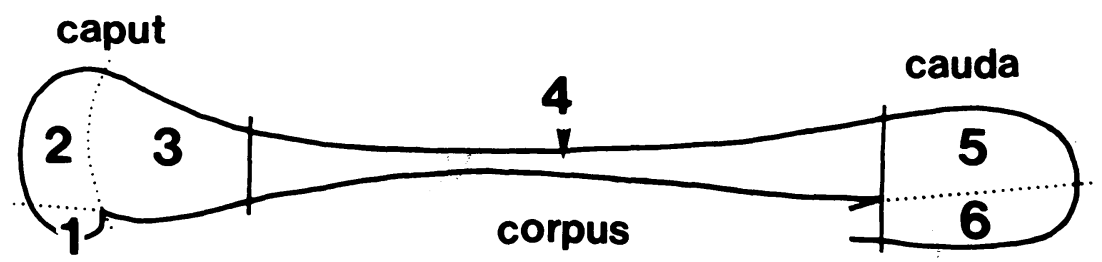

FIG. 2. Diagrammatic illustration of epididymis. Epididymis was divided into six segments; proximal, middle, and distal parts of caput (segments 1, 2, and 3), corpus (segment 4), and proximal and distal parts of cauda (segments 5 and 6). 

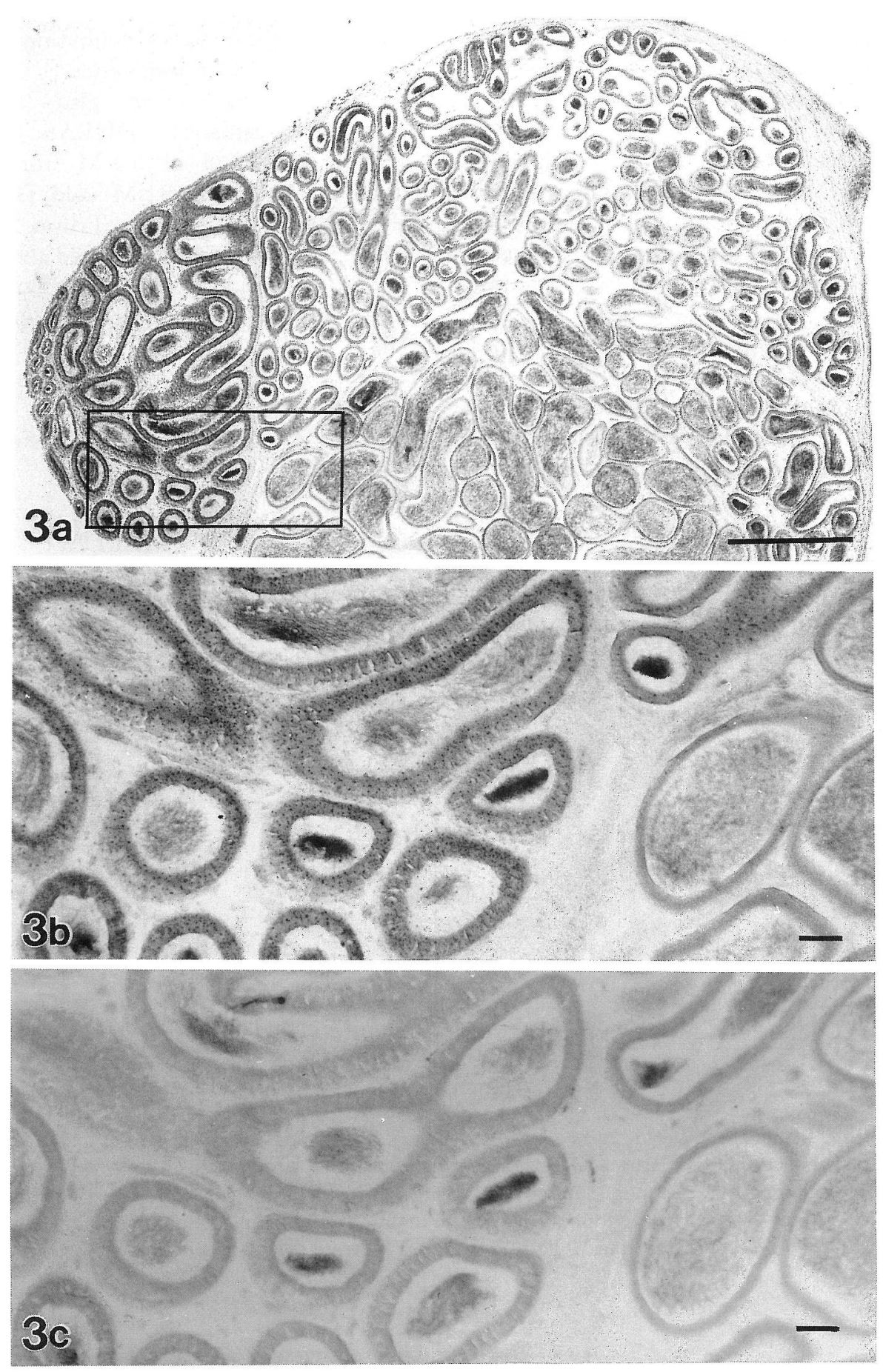

FIGS. 3a-c. Light micrographs of caput of epididymis showing enzyme-histochemical distribution of steroid sulfatase. 3a. High activity is demonstrated in the proximal part of caput as purple staining (dark staining in this photograph). Because of yellowish background staining, duct contents are shown dark. Bar=1 mm. 3b. Higher magnification of boxed section of 3a. 3c. An adjacent section incubated with medium containing $2 \mathrm{mM}$ DHEAS. Although background staining is observed in luminal contents and epithelium, enzymatic reaction is completely inhibited. Bars $=100 \mu \mathrm{m}$. 
P42C2 to epididymal steroid sulfatase (Fig. 1). Steroid sulfatase was not bound to normal mouse IgGSepharose (Fig. 1A) but almost completely to P42C2Sepharose (Fig. 1B). About $60 \%$ of the bound enzyme was eluted with an alkaline solution containing
$10 \%$ dioxane, although concentration of protein in the eluate was undetected with a highly sensitive method using bicinchoninic acid.

Light microscopic enzyme-histochemistry: By the azo coupling dye method, the strongest staining was
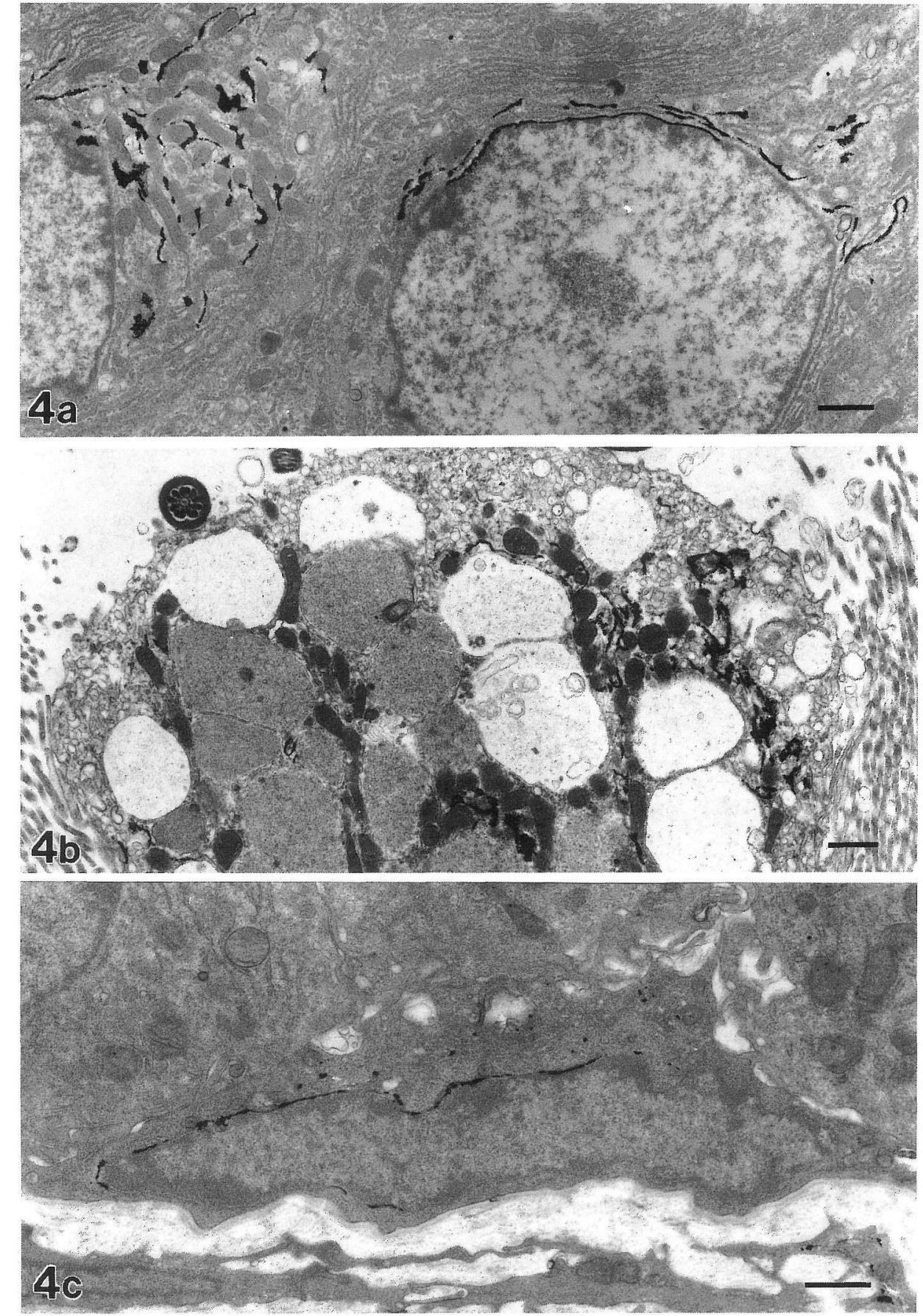

Figs. 4a-c. Electron micrographs showing localization of steroid sulfatase activity. 4a. Principal cells in proximal caput. 4b. Apical part of caudal clear cell. 4c. Caudal basal cell. Reaction product is found along nuclear envelope and endoplasmic reticulum. $\mathrm{Bar}=1 \mu \mathrm{m}$. 

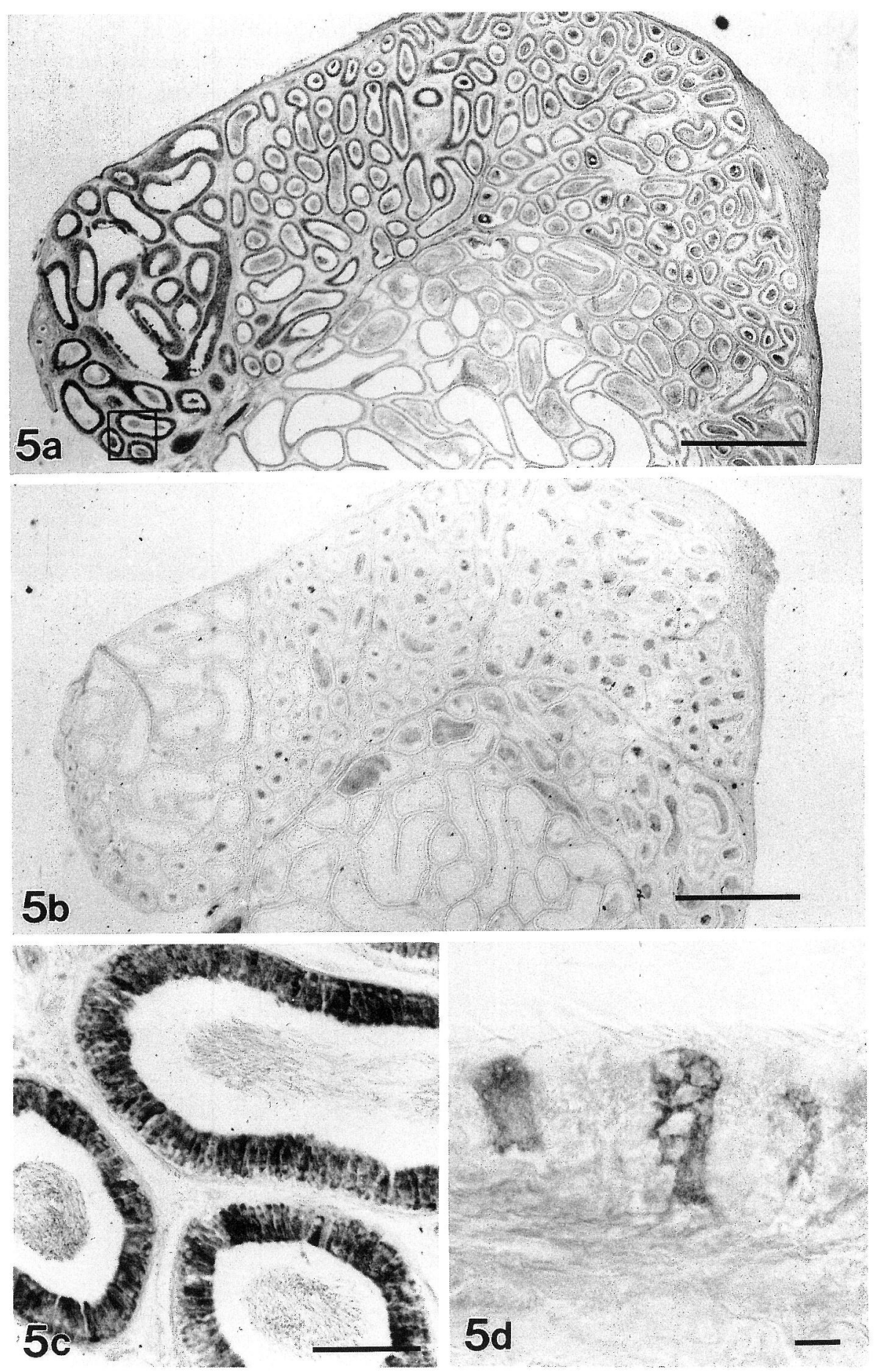

FIGs. 5a-d. Indirect immunoperoxidase staining of steroid sulfatase. 5a. Proximal part of caput is strongly stained. Staining gradually decreases caudally. Box is magnified in 5c. 5b. Control of 5a stained without primary antibody. Bars $=100 \mu \mathrm{m}$. $5 \mathrm{c}$. Epididymal ducts of proximal part of caput show strong staining. 5d. Epididymal duct epithelium in cauda. Immunostaining is shown in clear cells, Bars $=10 \mu \mathrm{m}$. 
detected in the proximal part of the caput (segment 1 ) (Figs. 3a, b). In the middle part of the caput (segment 2), staining gradually decreased to a very low level. No clear staining was observed in the distal part of the caput (segment 3), the corpus (segment 4), or the cauda (segments 5 and 6). Sections incubated without the substrate or with a medium containing the competitive inhibitor DHEAS $(2 \mathrm{mM})$ showed yellowish background staining only (Fig. 3c).

Electron microscopic enzyme-histochemistry: Using
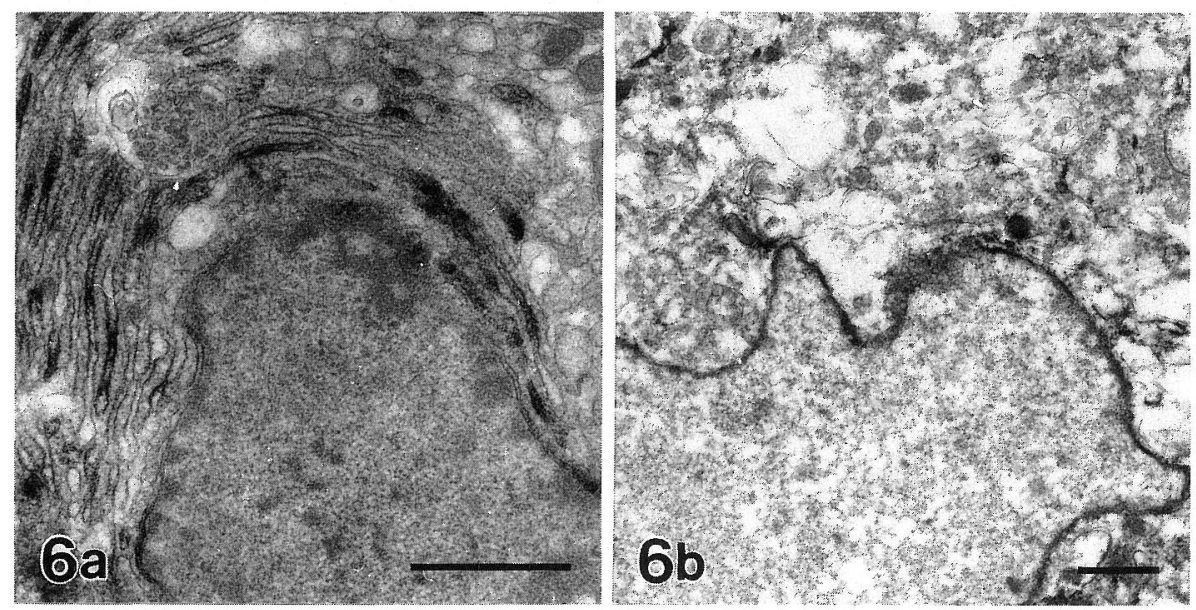

FIGs. 6a, b. Electron micrographs showing indirect immunoperoxidase staining of steroid sulfatase. 6a. Principal cell in proximal part of caput. 6b. Clear cell in cauda. Deposit is localized along nuclear envelope and endoplasmic reticulum. Bars $=1 \mu \mathrm{m}$.

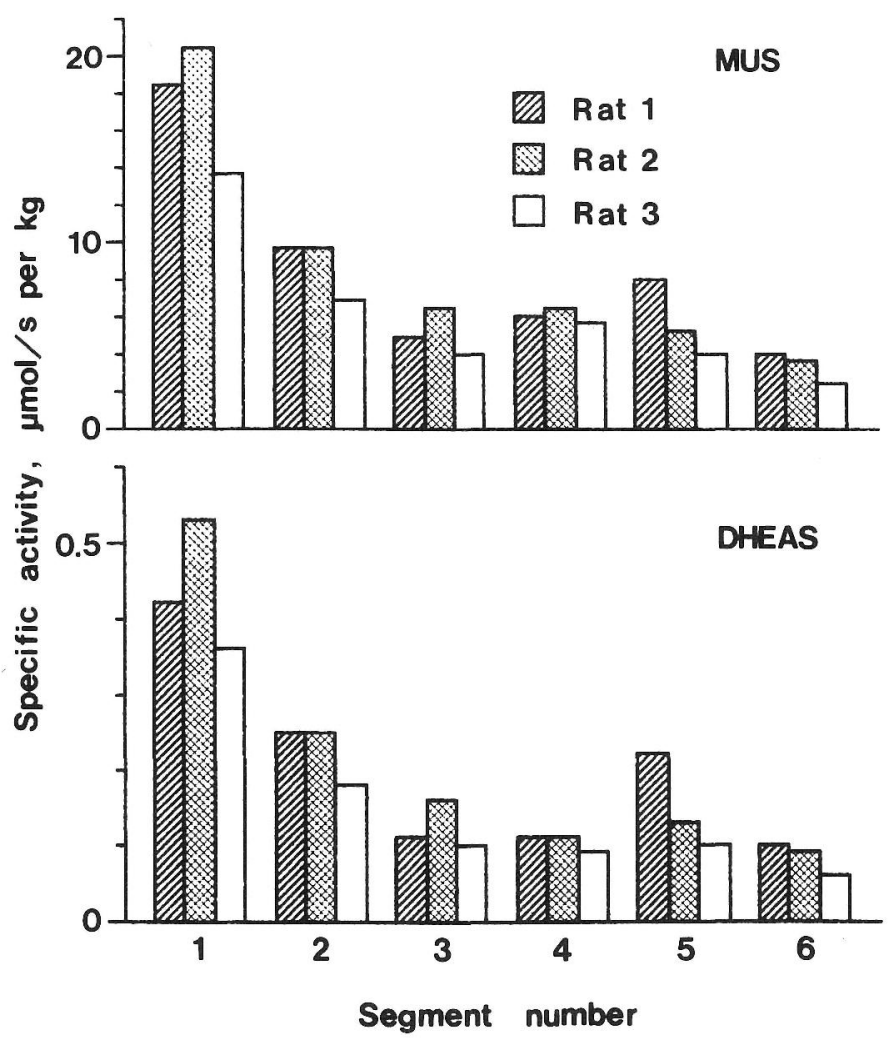

FIG. 7. Regional distribution of steroid sulfatase activity in epididymis. Activities hydrolyzing MUS and DHEAS show identical distribution patterns in three rats (Rats 1,2, and 3). Highest activity is distributed in proximal part of caput (segment 1), decreasing in caudal part of caput (segment 3). Generally, corpus (segment 4) and cauda (segments 5 and 6) have low activity. 
the metal precipitation method, we detected enzyme activity along the nuclear envelopes and endoplasmic reticulum of principal cells of segment 1 (Fig. 4a), in clear cells of segments 4-6 (Fig. 4b), and in basal cells throughout the epididymis (Fig. 4c). A smaller amount of the precipitate was observed in some principal cells of segments 2-6 (data not shown). Tissues incubated without substrate showed no barium sulfate precipitation (data not shown).

Light microscopic immuno-histochemistry: Light microscopic immuno-histochemical studies using a monoclonal antibody to steroid sulfatase showed a staining pattern (Fig. 5) similar to that of the light microscopic enzyme-histochemical study. Specific staining was the strongest in segment 1 of epididymal ducts (Figs. 5b, c), declined in segment 2, and was very weak in segment 3 (Fig. 5a). In segments 4-6, principal cells were not stained, although clear cells were weakly stained (Fig. 5d). Non-specific binding of secondary antibody and endogenous peroxidase activity was negligible (Fig. 5b). We also confirmed no binding of normal mouse IgG to tissue sections (data not shown).

Electron microscopic immuno-histochemistry: It was shown that monoclonal antibody bound to membranes of the nuclear envelopes and endoplasmic reticulum of principal cells of segment 1 (Fig. 6a) and clear cells in segments 4-6 (Fig. 6b). Non-specific binding of normal mouse IgG and secondary antibody and endogenous peroxidase activity was negligible (data not shown).

Biochemical analysis: Distribution of the enzyme was also studied by biochemical techniques. When MUS was used as substrate, segment 1 showed the highest activity (Fig. 7a). Segments 3-6 had about $25 \%$ as much activity, and segment 2 about $50 \%$. The enzyme was also assayed using DHEAS (Fig. 7b). Although specific activity of each segment was about 1/40 of that of MUS, the distribution pattern of enzyme activity was identical.

\section{DISCUSSION}

Using light microscopic enzyme-histochemical and immuno-histochemical methods, we detected steroid sulfatase in the epididymal duct (Figs. 3, 5). The azo coupling dye method revealed that the strongest staining was distributed in the proximal part of the caput (segment 1). Somewhat less staining was observed in the medial caput (segment 2), and faint or negligible staining in the distal caput (segment 3), corpus, and cauda (segments 4-6). The immunohistochemical method provided compatible stainings with those of enzyme-histochemistry except in segments 4-6. Clear cells in segments 4-6 were weakly stained with a monoclonal antibody, P42G2 (Fig. $5 d)$.

Ultrastructural enzyme-histochemistry and immuno-histochemistry using the metal precipitation method and P42C2 monoclonal antibody, respectively, provided intracellular localization of this enzyme as previously described elsewhere $(4,5,7)$. Endoplasmic reticulum and nuclear envelopes of various epithelial cells were consistently stained with both methods (Figs. 4, 6). There is no discrepancy between enzyme-histochemistry and immuno-histochemistry at the ultrastructural level. The metal precipitation method revealed steroid sulfatase activity of the clear cells even in the caudal part (segments 46 ), where reaction of the azo coupling dye method was negligible, indicating that the metal precipitation method is more sensitive.

In biochemical assays of steroid sulfatase, the highest activity was shown in segment $1,50 \%$ less in segment 2, and 75\% less in segments 3-6 (Fig. 7). This distribution pattern is quite similar to those obtained from the present histochemical studies. Since the relative percentile contributions of principal, basal, and clear cells in segments 4-6 is about 70, 20, and $10 \%$, respectively (10), activity in these regions seems to be caused not only by clear cells, but also by principal and basal cells as shown by electron microscopic enzyme-histochemistry.

It should be noted that the distribution of steroid sulfatase is similar to that of estradiol binding sites in the mouse epididymis. Schleicher et al. (11) showed that the number of grains over principal cell nuclei after tritiated estradiol administration was highest in the proximal part of the mouse caput epididymis, and that it declined caudally, with labeling low or absent in corpus and cauda, where clear cells rather than principal cells were heavily labeled. They also showed that binding sites for dihydrotestosterone were allocated independently of estradiol binding sites. This suggests that steroid sulfatase is concerned with estradiol uptake of the epididymal duct but not with dihydrotestosterone uptake.

It is quite interesting that the initial segment of the mouse epididymal duct (corresponding to segment 1 of the rat epididymis used in our studies) is surrounded with a dense network of fenestrated capillaries running just under the epithelium (1). In addition, it has been shown that estrone sulfate and DHEAS are present in much higher concentrations in boar testis than elsewhere throughout the body, and their concentrations in blood plasma and lymph sharply rise with the 
appearance of spermatozoa in the testis (12). These sulfated steroids in the circulatory system or the epididymal duct fluid seem to enter into the epididymal epithelium, especially in the proximal part of the caput (segment 1), where they are hydrolyzed to free steroids by steroid sulfatase, and then may be converted to estradiol.

The functional role of steroid sulfatase in the epididymis should be further investigated.

\section{ACKNOWLEDGEMENT}

We thank Dr. K. Toshimori, Department of Anatomy, Miyazaki Medical College, and Dr. H. Takano, Department of Anatomy, Hokkaido University School of Medicine for their valuable discussion and Dr. R. J. Adams, Department of English, Miyazaki Medical College for reviewing the manuscript.

\section{REFERENCES}

1. Abe, K., Takano, H. and Ito, T.: Microvasculature of the mouse epididymis, with special reference to fenestrated capillaries localized in the initial segment. Anat. Rec. 209; 209-218, 1984.

2. Bradford, M. M.: A rapid and sensitive method for the quantitation of microgram quantities of protein utilizing the principle of protein-dye binding. Anal. Biochem. 72; 248-254, 1976.

3. Daniel, W. L.: Arylsulfatase $\mathrm{G}$ and the steroid sulfatases. In Isozymes: Current Topics in Biological and Medical Research, vol. 12, ed. by M. C. Rattazzi $e t$ al., Alan R. Liss, New York, 1985, p. 189.

4. Kawano, J. and Aikawa, E.: Regional distribution of aryl-sulfatase $\mathrm{C}$ and estrone-sulfate sulfatase activities in rat brain and hypophysis. Brain Research 409; 391-394, 1987.
5. Kawano, J. and Aikawa, E.: Ultrastructural localization of arylsulfatase $\mathrm{C}$ activity in rat kidney. J. Histochem. Cytochem. 35; 523-530, 1987.

6. Kawano, J., Kotani, T., Ohtaki, S., Minamino, N., Matsuo, H., Oinuma, T. and Aikawa, E.: Characterization of rat and human steroid sulfatases. Biochim. Biophys. Acta 997; 199-205, 1989.

7. Kawano, J., Kotani, T., Umeki, K., Oinuma, T., Ohtaki, S. and Aikawa, E.: A monoclonal antibody to rat liver arylsulfatase $\mathrm{C}$ and its application in immunohistochemistry. J. Histochem. Cytochem. 37; 683690, 1989.

8. Meyer, J. G., Groh, V., Giger, V., Weiss, H., Varbelow, H. and Schnyder, U. W.: Rapid laboratory diagnostic of X-linked ichthyosis. Dermatologica 164; 249-257, 1982.

9. Reid, B. L. and Cleland, K. W.: The structure and function of the epididymis. I. The histology of the rat epididymis. Aust. J. Zool. 5; 223-246, 1957.

10. Robaire, B. and Hermo, L.: Efferent ducts, epididymis, and vas deferens: Structure, functions, and their regulation. In The Physiology of Reproduction, ed. by K. Knobil et al., Raven Press, Ltd., New York, 1988, p. 999.

11. Schleicher, G., Drews, U., Stumpf, W. E. and Sar, M.: Differential distribution of dihydrotestosterone and estradiol binding sites in the epididymis of the mouse. An autoradiographic study. Histochemistry $81 ; 139-147$, 1984.

12. Setchell, B. P., Laurie, M. S., Flint, A. P. E. and Heap, R. B.: Transport of free and conjugated steroids from the boar testis in lymph, venous blood and rete testis fluid. J. Endocrinol. 96; 127-136, 1983.

13. Sorensen, K. and Brodbeck, U.: A sensitive protein assay method using micro-titer plates. Experientia 42; 161-162, 1985.

14. van der Loos, C. M., Volkers, H. H., Tigges, A. J., Meijer, A. E. F. H. and Jobsis, A. C.: Combined histochemical and biochemical investigation to the reliability of the demonstration of arylsulphatase activity in cryostat sections. Histochemistry 62; 259-269, 1979. 